\title{
The Application of Games in English Vocabulary Teaching in Kindergartens
}

\author{
LIU Shuang, LIU Jin-xia \\ Linyi University, Linyi, China
}

\begin{abstract}
The paper tries to explore how to use games in teaching English vocabulary in kindergartens. It starts with the introduction of definitions of the game and the characteristics of the game, then lists the types of the game. Based on an analysis of present situation of English vocabulary teaching in kindergartens, the author points out the importance of teaching English vocabulary through games in kindergarten. Finally, the author explains how to use games to teach English vocabulary in kindergartens.

Keywords: English teaching, games, vocabulary
\end{abstract}

\section{Introduction}

In recent years, a lot of educators have realized that remembering vocabularies mechanically is the most boring part in English learning and they begin to pay much more attention to use games for English teaching, especially for vocabulary teaching. According to YU Zhen-you (1999), teaching aims in preschool English education are to foster children's English learning interests. And the game teaching is the best way to inspire children's learning interests and set up a realistic and communicative language learning environment for English study. Thus many papers have been written to tell teachers how important of using games in vocabulary teaching and advise them how to carry out games in vocabulary teaching. However, most of them focus on teaching vocabulary in primary, middle, and high school and ignore the importance of applying games to vocabulary teaching in preschool. Further, almost no one attaches importance to it and applies it into the English teaching of children. The aim of this paper is through the application of games in kindergartens to improve the enthusiasm of learning vocabulary, cultivate children's team spirit and cooperative consciousness, and accelerate children's comprehensive abilities.

\section{Literature Review on Games}

\section{Definition of the Games}

Owning to different understandings of the games, researchers have different standpoints and the different definitions of the games. For example, Jill Hadfield (1984) defines games as "an activity with rules, a goal and an element of fun" (p. 115). Spodek Bernard and Saracho Olivia (1994) hold a similar opinion that games are "a

LIU Shuang, B.A., School of Foreign Languages, Linyi University.

LIU Jin-xia, professor, M.A., School of Foreign Languages, Linyi University. 
different kind of playing activities which include specific rules and are well structured" (p. 271). Besides, Deesri (2002) give the definition that "they are not just a diversion, a break from routine activities, but a way of getting the learner to use the language in the course of the game" (p. 22). According to Fredericksen (1999), games are what "create a bridge between learning and doing" (p. 46). Based on the definitions the author have read, the author's understanding of the game should involve many factors: rules, competition, relaxation, and learning, and the focus of using game in kindergartens is to help children learn through fun.

\section{Characteristics of Using Games in English Vocabulary}

Generally speaking, characteristics of the games should include the following:

Purpose. "There is a common perception that all learning should be serious and solemn in nature and that if one is having fun and there is hilarity and laughter, then it is not really learning. This is a misconception. It is possible to learn a language as well as enjoy oneself at the same time" (Lee, 1995, p. 35). Namely, the game as a form of activity, the purpose is to arouse infants' interests, to make children participate in the activities actively, and finally to complete the goal that teachers set. Thus, no matter how teachers design the game, they should pay attention to some notes: They must always consider the teaching aims, control the key factor in the process of the game, and not only focus on the entertainment of the game, but also its educational meaning. More important thing is that they should not ignore the learning effect on children. The ultimate goal of the game is to improve the teaching quality. Therefore, when choosing games, teachers should pay close attention to the purpose of the game that combines with teaching activities.

Appropriateness. Owning to the different characteristics of children's mind and body, children's abilities of acceptance are not the same. Therefore, when using games in class, the teachers should consider children's level of acceptance and start game from simple to complex, and then gradually make the game harder. The game must be appropriate for children. If games were too difficult for most of children in kindergartens to accept and understand, they would weaken the motivation and enthusiasm for children to learn. Besides, the teachers should take children's gender into consideration and choose the different games that not only suit for boys but also are accepted by girls. For example, if a teacher plays a tug or racing game with children, the results may lean to boys, while handcrafted games like paper cuts may be liked by girls. Therefore, it is very necessary for teachers to choose the appropriate game for children on the basis of their interests, gender, the ability of acceptance, and the children's mental and physical development.

Interesting. In the education activities, teachers should design the class in line with the law of children's physical and mental development and their learning level, the education content and teaching methods. Through making full use of the English game, it can create a good English environment and a relaxed learning atmosphere which arouse kids' interests and attention in learning English and "it is necessary and important to cultivate students' indirect learning purpose and task" (ZHANG, 1999, p. 99). Besides, the game is full of unlimited fun in the process of learning a language that can enrich children's ability of understanding English and strengthen children's memory of language.

Competitiveness. Infants like to express themselves and compete with others. Therefore, it is an indispensable way to use competition mechanism like a flower or a star which also provides encouragement to the progressive child to stimulate the enthusiasm in learning vocabulary. Research suggested that "learning, as 
well as effective variables are enhanced by a cooperative and competitive environment" (Johnson, Stanne, \& Slavin, 2000, p. 95). So, teacher should place importance on the fairness of competition to make the evaluation reasonable under the environment full of lively atmosphere.

Diversity. As we all know that the environment we live in is full of diverse attraction, especially for children who are curious about the world. Therefore, the diversification of the game teaching is the key factor to attract children's attention in learning English. QIU Xue-qing (2005) holds that teachers should attach importance to devise various games. Therefore, it is teachers' duty to provide a variety of games suited for children to arouse children's interests and meet their curiosities to learn from games. The important thing teachers must keep in mind is that they should put the meaning of games in the first place when they pay attention to the diversification of the games.

Above all, only when the teachers make full use of the characteristics of games in English teaching, can they stimulate the interests of children to learn English vocabulary and enjoy the process of learning English vocabulary through games.

\section{Types of the Games}

There are two types of games in the classroom, one type stresses accuracy which is called language-focused games and the other stresses fluency, which is called communication-focused games. The language-focused games include Bingo Games, Guessing Games, Chinese Whisper, Musical Chairs, Counting Games, Simon Says, and so on, and the Communication-focused games like Describe and Draw Games, Spot the differences in a game, and so on. LU Zi-wen (2004) points that "this kind of classification is convenient for teachers design and choose appropriate games to carry out relevant teaching activities" (p. 17). So, teachers should choose different types of games to arouse children's interests on the basis of satisfying children's different needs in learning English. Through providing all kinds of games, children can get interested in learn English words in the process of enjoying the mystery of all kinds of games.

\section{Necessity of Teaching Vocabulary Through Game in Kindergartens}

\section{The Present Situation of Vocabulary Teaching in Kindergartens}

Chinese characters as our native language are simpler for us to learn than English on the basis of the surroundings that we are living in. Therefore, creating a suitable atmosphere for English teaching and learning is indispensable for children in kindergartens to learn English vocabulary. Though more and more people have realized the importance of atmosphere in preschool and also paid more attention to use games in learning vocabulary in kindergartens, there are many aspects that have been ignored which affect the characteristics of body and mind of the children.

\section{Unsuited Teaching Methods in Kindergartens}

Whether we should teach English in kindergarten has always been a hot topic and affected a lot of children, parents, and some teachers. However, there are some unsuited teaching methods that have a bad effect on the children's physical and mental health. For example, some teachers think highly of the ability of speaking English and ignore the importance of vocabulary. Actually, we should put them in the same position, improve not only the ability of communication but also their cognitive competence. Also, teachers often think highly of how to 
keep words in mind rather than teach children how to learn through games in the relaxed and interesting environment. Besides, when teaching vocabulary, teachers get used to teach children how to read words and make children read again and again. However, this phenomenon is so common among the kindergarten that affects the quality of children and the interests of children.

\section{Lack of Interests in Learning Vocabulary}

We all know that curiosity is the best teacher. So, interest is very important for us, especially for children. If we just infuse some vocabulary to them without considering children's interests, it is hard for them to learn the words and they will get tired of the learning.

Therefore, it is necessary for teachers to adapt new methods like games to arouse their interests. For example, in "Guessing Game", teachers should design interesting games to attract infants' attention. When teaching the words about "color", the teachers should prepare a box containing eggs that are painted in different colors, on the condition that students know what color is in the box first, then take one of them to make children guess that which color is missing. Through practicing step by step, the students' curiosity will gradually arouse and the ability of recognizing words is improving. In a word, teachers should constantly design innovative game to stimulate infants' learning interests.

\section{The Significance of Teaching Through Games in Kindergartens}

Game as the main form of activity is the basic means of education for kids and can "excite children learning interest effectively; promote the development of children's intelligence; and train children's innovation ability" (DING, 2001, p. 89). Besides, game teaching is one kind of efficient teaching method that teachers can transform dull language into interesting games which children are happy to accept in teaching practice, and is the best method to learn English, especially for learning vocabulary.

The game teaching is of great significance for children. CHEN He-qin (2010), the representative educator in 1920s, holds that games not only make children lively and arouse children's learning interest, but also can provide help for teachers as an effective teaching method. When playing a group game, children have the chance to cooperate with others and they can have the chance to show their talent to develop communication skills and language skills in the game. The game teaching as a very crucial method plays a very momentous role in English vocabulary for children; it is the best way to stimulate their motivation and inspire their greater enthusiasm for English learning. In the process of the activity, children can improve their self-confidence through hard-working which lays a solid foundation in their language learning. Therefore, as a teacher, when using games to teach English vocabulary in kindergartens, they should take the characteristics of children's mind and body into consideration and make full use of games combining with the learning vocabulary to improve children's abilities of imagination and the interests to learn.

Specifically, the game teaching is a kind of teaching mode with game as the main way of English teaching activity. Similarly, games can also "as a way to revise and recycle previously taught language" (Ubemall, 1978, p. 98). In other words, it is a kind of English game activity that children take part in the game as a character under the game rules created by teachers. This method integrates teaching content into games, and activates children's thinking in a playful manner considering children's physical and mental characteristics. Also, it unknowingly achieves internalization of language knowledge and improves their sensitivity to context and communicative 
objects to boost their communication ability and self learning ability, and enables children to learn by playing through creating rich language communication scenarios.

\section{Ways of Teaching Vocabulary Through Games in Kindergartens}

As we all know that being active is a natural way of having fun for children, thus the teachers should not only take the application of games itself into consideration, but also focus on how to make them enjoy the learning English vocabulary experience through games. Therefore, when teaching English vocabulary, the teachers should put games in the first place and the priorities of the teaching second, then combine the teaching activity with game activity according to their respective teaching schedule. Besides, teachers should try their best to induce children into the situations in teaching vocabulary with their exaggerated expressions or actions to educate children in kindergartens with purpose and plans that "based on scientific knowledge of children's psychology and physiology development” (LIANG, 2007, p. 9).

\section{How to Use Suitable Games}

CAO Ying-yan (2011) held that "the unscientific games teaching can easily result in low efficiency of game teaching in preschool English instruction" (p. 219). Therefore, when using games in kindergartens, it is a key factor for us to consider whether the game is suited for preschool children. Not only are children's development of their mind and body, and their hobbies considered, but also their current level of their English. Different age groups need different kinds of games; the teaching goals should vary from children's age and their vocabulary receptive ability. Hence, it is very necessary to use suitable games to teach their English vocabulary in kindergartens. However, it is not a simple task to choose and use suitable games among so many games. In short, the using of games should draw children's attention and interests in learning and make learning lively, visual, and full of fun. Therefore, the author will provide some games which can improve children's learning motivation according to her learning experiences in kindergartens.

The Using of material objects to vocabulary teaching. On the basis of the new curriculum standards, the education stresses that we should give full play to the autonomy of the students in the classroom teaching and make the combination of the learning in classroom and the practice. Therefore, material object as one of the most intuitive teaching aids in the classroom, should be adapted to kindergartens for children. For example, when teachers want to teach them the vocabulary about body, firstly, let them stand up and stretch out their hand, when teaching vocabulary like "eye", "ear", "nose", and so on, the children respectively point to the part in their own bodies, whenever finding the wrongdoing, he or she should sit down at once unit the last one stand up still. Also, if teachers want to teach them the vocabulary about classroom, teachers can use material objective in the classroom, such as "desk", "window", "light", and so on. In the author's opinion, it is necessary to use material object to teach English vocabulary and it is their role as a bridge between classroom and practical life; if we apply some necessary material object into the practical teaching, it is easy to arouse the enthusiasm of learning vocabulary to children.

The using of flash cards to vocabulary teaching. We know that remembering vocabulary is not the primary mission for preschool children; what teachers should do is to teach them to recognize the basic vocabulary around their daily life through games in the relaxed and interesting environment. So Flash Cards can be chosen in kindergartens. Not only is it convenient for teachers to use, it is also an easy tool for children to 
accept in learning. Using Flash Card to guess English vocabulary is the most interesting among many functions in Flash Card. For example, teachers should choose some Flash Cards that can be prepared in advance in line with the teaching plans and the teaching contents, then divide the children into two groups and distribute different tasks to the two groups: One is charge of guessing the vocabulary in Flash Card; the other directs to express the meaning of the vocabulary with gesture, action, and other body languages. This way can not only improve children's abilities of imagination creativity, but also can cultivate children's team spirit and cooperative consciousness, and accelerate children's comprehensive abilities.

\section{Notes of Game Teaching in English Vocabulary in Kindergartens}

As an instructor, teacher should make use full of the games in children's learning. Meanwhile, teachers should pay more attention to the notes of game teaching in English vocabulary in kindergartens in case that many problems occur that affect the characteristics of body and mind of children.

Make adequate preparation. In order to make the English teaching more interesting and more significant for children, teachers should make preparation in advance, such as material preparation, knowledge preparation, and psychological preparation. Richard-Amato(1996) believes that games lower anxiety, thus making the acquisition of input likely. Therefore, full of preparation is a key factor to ensure the games that proceed smoothly in the environment full of relaxed and interesting atmosphere.

Make the game rules. In the process of some games, some violations of discipline will appear unavoidably owing to the competitive and aggressive characteristics. Therefore, teachers must give a detailed interpretation of the rules before the game, it is necessary for teachers to set up rewards and punishment system, fully mobilize the enthusiasm of the infants and keep discipline in the classroom.

Control the playtime. When teachers use games in English teaching, it is their duties to control the game time properly. Whether game time is suitable will affect the learning and teaching in kindergartens: If teachers spend too much to play games, it is easy for children to lose interests in the game and have a tendency to lose interests in further learning. On the other side, if teachers spend little time playing games, it will make children feel disappointed and their excitement and pleasure are forced to swallow, which will definitely have a harmful effect on the children's enthusiasm of participation and their motivation in learning. Therefore, teachers should control the length of the game time in line with children' social development level and regulate those games according to the children's interests, abilities, and teaching content.

\section{Conclusion}

The paper points out the purpose and the importance of using games based on the analysis of present situation of English vocabulary teaching in kindergartens. Applying games into English learning can create a situation for children as close to the real language environment as possible, make the learning more lively, and improve children's abilities of imagination, creativity, and language skills, but proper preparation, interpretation of the rules, and controlling of the time should be the necessary things the teacher should keep in mind .

\section{References}

CAO, Y. Y. (2011). The problems and countermeasures of English teaching in primary class (Master thesis, East China Normal University).

CHEN, H. Q. (2010). The collection of Chen Heqin. Nanjing: Jiangsu Education Press. 
Dessri, A. (2002). Teaching and Learning in the language classroom. Shanghai: Shanghai Foreign Language Education.

DING, H. D. (2001). The theory of preschool game. Jinan: Shandong People Press.

Frederocksen, E. (1999). Playing thought: Increasing literacy through interaction. Journal of Adolescent and Adult Literacy, 43, 116-124.

Hadfield, J. (1984). Elementary communication games. London: Nelson.

Johnson, D. W., Johnson, R. T., \& Stanne, M. B. (2000). Cooperative learning methods:A meta-analysis. University of Minnesota. Lee, S. K. (1995). The biological foundations of language. New York: John Wiley \& Sons.

LIANG, D. Q. (2007). The teaching researches and practices of game in primary school (Master thesis, Guangxi Normal University).

LU, Z. W. (2004). The Learning theory and practices in primary English. Beijing: China Electric Power Press.

QIU, X. Q. (2005). Games in preschool (pp 171-175). Nanjing: Jiangsu Education Press.

Richard-Amato, P. A. (1996). Making it happen:Interaction in the second language classroom (2nd ed.). New York: Longman. Spodek, B., \& Saracho, O. N. (1994). Right from the start: Teaching children ages three to eight. Boston: Allyn and Bacon.

Ubemall, A. (1978). The use of games for vocabulary presentation and revision. Beijing: Foreign of Language Teaching and Research Press.

YU, Z. Y. (1999). The instruction of activities in kindergarten. Nanjing: Nanjing Normal University Press.

ZHANG, Z. D. (1999). Foreign language education. Beijing: Science Press. 